\title{
Pengaruh Ozonisasi terhadap Kekerasan, Kadar Air, Vitamin C, dan Total Mikroorganisme pada Belimbing (Averrhoa carambola) Selama Penyimpanan
}

\author{
Effect of Ozonation on Firmness, Water Content, Vitamin C and Total Microorganism of Starfruit (Averrhoa carambola) \\ during Storage
}

\author{
Imas Siti Setiasih*, Tita Rialita, Debby Moody Sumanti, In In Hanidah, Gemma Zulhaida \\ DepartemenTeknologi Industri Pangan, Fakultas Teknologi Industri Pertanian, Universitas Padjadjaran, \\ Jl. Raya Bandung Sumedang km.21, Jatinangor 45363, Indonesia \\ *Email: imas.siti@unpad.ac.id
}

Tanggal submisi: 12 Maret 2017; Tanggal penerimaan: 30 November 2018

\begin{abstract}
ABSTRAK
Belimbing merupakan buah non-klimakterik yang mudah rusak setelah pemanenan dan selama penyimpanan. Salah satu senyawa yang dapat digunakan untuk mempertahankan kualitas belimbing adalah perendaman dalam air ozon. Penelitian ini bertujuan untuk membandingkan karakteristik belimbing utuh tanpa ozonisasi dan dengan ozonisasi menggunakan ozonizer TIP-01 selama penyimpanan pada suhu ruang $\left(25 \pm 2{ }^{\circ} \mathrm{C}\right)$. Metode penelitian dilakukan menggunakan metode eksperimental yang dilanjutkan dengan analisis korelasi regresi. Penelitian terdiri dari 2 perlakuan, yaitu belimbing utuh tanpa ozonisasi dan dengan ozonisasi yang dikemas menggunakan clingwrap dengan alas styrofoam. Hasil penelitian menunjukan belimbing dari kedua perlakuan mengalami penurunan kadar air, vitamin $C$ dan kekerasan. Perlakuan ozonasi pada konsentrasi $1,1 \mathrm{ppm}$ hanya mampu menghambat pertumbuhan mikroorganisme sebesar 0,34 log CFU/g. Belimbing utuh dengan ozonisasi memiliki kandungan vitamin C yang lebih tinggi dibandingkan dengan tanpa ozonisasi yaitu $31,97 \mathrm{mg} / 100 \mathrm{~g}$ bahan di akhir penyimpanan.
\end{abstract}

Kata kunci: Belimbing utuh; ozonasi; ozonizer TIP-01; karakteristik belimbing

\begin{abstract}
Starfruit is a non-climacteric fruit which are perishable after harvesting and during storage. One of compounds that can be used to maintain starfruit quality is the use of ozone water. This study was conducted to compare the characteristics of starfruit without ozonation and after ozonation using TIP-01 ozonizer during storage time in the room temperature $\left(25 \pm 2^{\circ} \mathrm{C}\right)$. The method used was the experimental method and then analyzed using a correlations-regressions analysis. The study used 2 treatments which were starfruit without ozonation and with ozonation (immersion in ozon water), the star fruits were packed by using a cling wrap with Styrofoam as the base. The results showed that starfruits from both treatments had changes in water content, vitamin $\mathrm{C}$, and firmness (decreased). Ozone treatment with a concentration of $1.1 \mathrm{ppm}$ was only able to inhibit the growth of microorganisms by $0.34 \mathrm{log}$ CFU/g. Starfruits' intact ozonation results in higher vitamin C content at 31.9680 $\mathrm{mg} / 100 \mathrm{~g}$ of material at the end of storage.
\end{abstract}

Keywords: Starfruit; ozonation; ozonizer tip-01; starfruit characteristics 


\section{PENDAHULUAN}

Buah-buahan merupakan salah satu komoditi hortikultura yang memiliki kontribusi dalam pengembangan pertanian di Indonesia. Prospek pengembangan buah-buahan di Indonesia ditunjukkan dengan jumlah produksi dan potensi pasar yang besar dan terus meningkat seiring permintaan masyarakat. Letak wilayah Indoneisa di daerah tropis sangat menguntungkan dalam bidang pertanian karena banyak komoditas buah-buahan yang dapat dibudidayakan, salah satunya adalah belimbing (Halimah, 2012). Data Badan Pusat Statistik dan Direktorat Jendral Hortikultura (2014) menunjukan bahwa produksi belimbing di Indonesia pada tahun 2010 sebesar 69,089 ton, tahun 2011 sebesar 80,853 ton, tahun 2012 sebesar 91,788 ton, tahun 2013 sebesar 79,634 ton, dan pada tahun 2014 sebesar 80,524 ton.

Belimbing merupakan salah satu buah-buahan yang bersifat mudah rusak (perishable), baik dari segi fisik, fisiologis, kimia maupun mikrobiologis. Kerusakankerusakan tersebut saling berikatan satu sama lain, kerusakan yang disebabkan oleh satu faktor dapat memicu kerusakan lainnya. Hal ini menyebabkan kualitas buah yang dihasilkan rendah. Kualitas buah yang rendah berdampak pada gagalnya buah menembus pasaran ekspor.

Kerusakan pada belimbing terjadi akibat proses respirasi dan transpirasi yang masih berlangsung setelah buah dipanen. Proses tersebut menyebabkan penurunan kualitas cepat terjadi dan menyebabkan masa simpan buah menjadi pendek. Kerusakan belimbing ditandai dengan terdapatnya bintik-bintik coklat pada permukaan buah serta pencoklatan pada sirip buah. Seiring bertambahnya waktu penyimpanan, kerusakan tersebut akan semakin besar sehingga belimbing tidak termanfaatkan secara maksimal bahkan tidak layak konsumsi. Menurut O'Donnell dkk. (2012) dan Sung dkk.(2014), penanganan pasca panen yang tepat perlu dilakukan untuk mengurangi mikroorganisme yang terdapat secara alami pada buahbuahan. Penanganan pasca panen berupa ozonisasi mampu mengurangi jumlah mikrooganisme pembusuk dan mampu mereduksi pestisida yang terdapat pada buah-buahan

Pada tahun 2001 Food and Drugs Administration (FDA) telah menyatakan bahwa ozon dapat berperan sebagai antimikrobial yang aman untuk perlakuan, penyimpanan dan pengolahan pangan. Ozon akan bereaksi dengan molekul kimia dari pestisida menyebabkan molekul kimia tersebut terurai menjadi senyawa yang lebih sederhana dan tidak toksik, sehingga efek karsinogenik dari pestisida dapat berkurang (Musaddad, 2013). Hal ini dapat menjadi solusi untuk meminimalisir kerusakan buah sehingga umur simpannya menjadi lebih panjang dan dapat menjadi solusi bagi konsumen yang menginginkan buah-buahan segar yang bebas dari pestisida. Penelitian ini bertujuan untuk mengetahui pengaruh ozonisasi terhadap karakteristik fisik (kekerasan), kimia (kadar air dan vitamin C), dan mikrobiologis (jumlah total mikroorganisme) buah belimbing segar selama penyimpanan suhu kamar $\left(25 \pm 2{ }^{\circ} \mathrm{C}\right)$. Sebagai variabel bebas adalah lama penyimpanan, sedangkan variabel terikat adalah nilai kekerasan, vitamin C, dan jumlah total mikroorganisme.

\section{METODE PENELITIAN}

Kriteria pengamatan utama terdiri dari kekerasan, kadar air, vitamin C, dan jumlah total mikroorganisme. Metode penelitian yang digunakan adalah metode percobaan eksperimental ( 2 kali ulangan) dan dilanjutkan dengan analisis regresi dan korelasi dimana variabel bebas ( $\mathrm{x}$ ) adalah lama penyimpanan dan perlakuan dengan ozon (BO) dan (BTO), sedangkan variabel terikat (y) adalah nilai kekerasan (alat penetrometer, JTEP), kadar air (AOAC, 2005), vitamin C (Karinda dkk., 2013), dan jumlah total mikroorganisme (BPOM, 2008). Rincian perlakuan yang dilakukan adalah:

$A=$ Belimbing utuh tanpa perendaman (BTO)

$\mathrm{B}=$ Belimbing utuh yang direndam dalam air berozon $1,1 \mathrm{ppm}$ selama 5 menit (BO)

\section{Bahan}

Belimbing dengan kematangan indeks- 6 dan berat $\pm 250 \mathrm{~g}$ yang diperoleh dari Depok, aquades, amylum (Merck, Jerman), larutan Iodium 0,01 N (Merck, Jerman), DPD total chlorine (Merck, Jerman), $\mathrm{NaCl}$ 0,85\% (Merck, Jerman), media Plate Count Agar /PCA (Merck, Jerman), kapas, kain kassa, gas oksigen murni (90-95\%), clingwrap, wadah Styrofoam.

\section{Alat}

Peralatan yang digunakan adalah ozonizer TIP01, ozone test kit, sentrifus (Thermo Scientific, US), pipet volume, klem, statif, Erlenmeyer (Pyrex, Jerman), bulb, cawan alumunium, oven (Memmert, US), desikator, neraca analitik (Ohauss, US), pisau, spatula, refraktometer (Thermo Scientific, US), autoklaf (All American, US), finntip (Thermo Scientific, US), pisau, beaker glass (Pyrex, Jerman), incubator (VWR Scientific Model 1525, US). 


\section{HASIL DAN PEMBAHASAN}

\section{Kekerasan}

Kekerasan merupakan salah satu parameter yang sangat menentukan kualitas produk hortikultura. Kekerasan dari buah juga akan mempengaruhi kesukaan konsumen terhadap produk. Kurva kekerasan belimbing utuh selama penyimpanan 28 hari berbentuk polynomial kuadratik (Gambar 1).

Persamaan pada Gambar 1 memiliki arti bahwa hubungan antara lama penyimpanan terhadap kekerasan belimbing bersifat polynomial kuadratik negatif atau mengalami penurunan kekerasan untuk kedua sampel. Hubungan tersebut menunjukan setiap lama penyimpanan 2 hari, nilai kekerasan pada BTO akan menurun sebesar 0,0467, sedangkan pada BO sebesar 0,0539. Angka tersebut menunjukkan laju penurunan kekerasan pada BO lebih cepat dibandingkan BTO.

Penurunan kekerasan buah pada BO dan BTO selama penyimpanan disebabkan oleh degradasi hemiselulosa dan pektin menjadi asam pektat yang larut dalam air (Chauhan dkk., 2011). Menurut Martin dkk. (2011) nilai kekerasan buah yang terus menurun disebabkan adanya proses pemecahan polimer karbohidrat khususnya pektin dan hemiselulosa, sehingga dinding sel melemah dan turunnya gaya kohesif yang mengikat sel yang satu dengan sel lainnya. Laju degradasi senyawa pektin ini secara langsung berhubungan dengan laju pelunakan buah. Perubahan zat-zat pektin pada belimbing terjadi selama pematangan buah, sehingga mengakibatkan kekerasan buah berkurang dan buah menjadi lunak. Penurunan kekerasan pada BO dan BTO selama penyimpanan disebabkan oleh degradasi hemiselulosa dan pektin menjadi asam pektin yang larut dalam air (Syafutri, Pratam, dan Saputra., 2006).

Kekerasan BTO maupun BO mengalami peningkatan yang cukup besar pada hari ke-16 dan
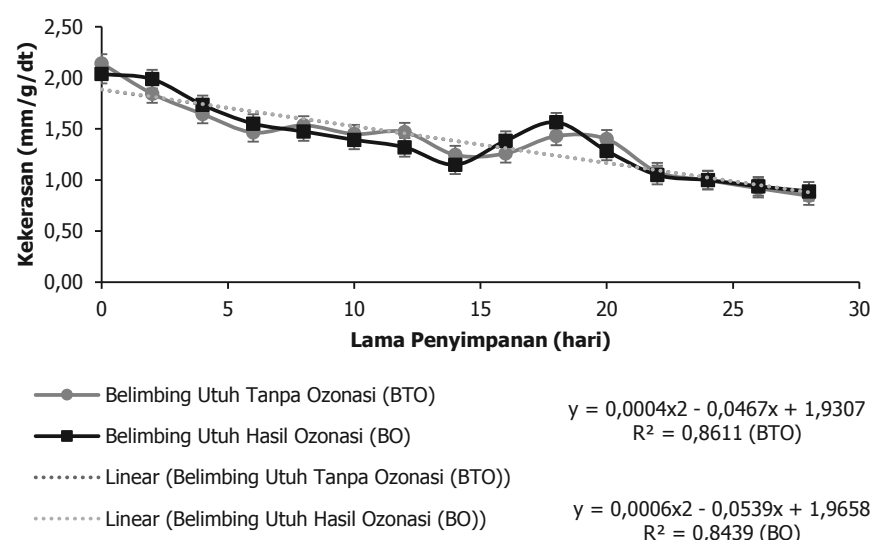

$$
\begin{gathered}
y=0,0004 \times 2-0,0467 x+1,9307 \\
R^{2}=0,8611(\text { BTO) } \\
y=0,0006 \times 2-0,0539 x+1,9658 \\
R^{2}=0.8439(B O)
\end{gathered}
$$

Gambar 1. Grafik kekerasan BTO dan BO selama penyimpanan buah belimbing pada suhu ruang ke-18, kemudian menurun kembali pada hari ke-20 hingga ke-28. Peningkatan kekerasan ini diduga akibat adanya pengaruh perubahan $\mathrm{RH}$ lingkungan selama penyimpanan. Berdasarkan garis standar polynomial dan grafik pada Gambar 1, garis saling berhimpit pada hampir tiap titik pengamatan. Hal ini menunjukan cenderung tidak terdapat perbedaan antara dua perlakuan. Hasil tersebut sesuai dengan penelitian Wei dkk. (2007), yang menyebutkan bahwa perlakuan ozonasi tidak berpengaruh pada kekerasan selada. Belimbing memiliki kandungan air yang sangat tinggi, sehingga laju respirasi cenderung tinggi. Penurunan kekerasan pada belimbing juga berhubungan dengan menurunnya kadar air pada bahan.

\section{Vitamin C}

Grafik perubahan vitamin $C$ pada belimbing utuh selama penyimpanan 28 hari berbentuk polynomial kuadratik (Gambar 2). Persamaan pada Gambar 2 memiliki arti bahwa hubungan antara lama penyimpanan belimbing dengan kandungan vitamin $\mathrm{C}$ bersifat polynomial kuadratik negatif atau mengalami penurunan untuk kedua sampel. Hubungan tersebut menunjukan setiap lama penyimpanan 2 hari, kandungan vitamin $C$ pada BTO akan menurun sebesar 0,25 , sedangkan pada BO sebesar 0,23. Angka tersebut menunjukkan laju penurunan vitamin C pada BTO lebih cepat dibandingkan BO.

Belimbing hasil ozonisasi (BO) memilikikadarvitamin C sebesar 31,97-39,01 mg/100 g bahan, sedangkan BTO sebesar 30,49-38,03 mg/100 g bahan selama penyimpanan. Dapat disimpulkan bahwa BO memiliki kadar vitamin C yang lebih tinggi dibandingkan BTO. Hal tersebut disebabkan ozonasi dapat menghambat enzim peroksidase askorbat atau oksidase askorbat, dimana enzim tersebut dapat menyebabkan proses oksidasi. Hal ini sesuai dengan penelitian Manaco dkk. (2014),

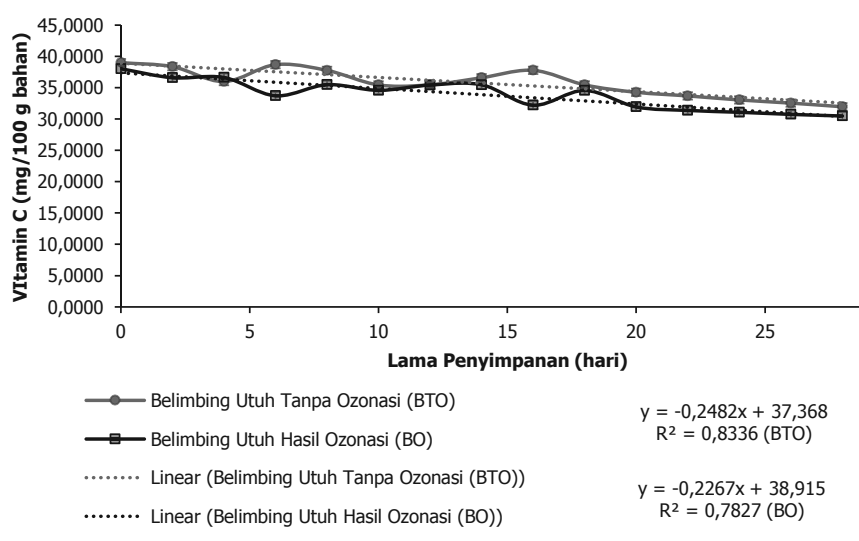

Gambar 2. Grafik vitamin C pada BTO dan BO belimbing selama penyimpanan pada suhu ruang 
dimana ozonisasi dapat meningkatkan vitamin $\mathrm{C}$ pada buah mangga akibat terhambatnya enzim peroksidase askorbat atau oksidase askorbat.

Seiring dengan lama penyimpanan, kadar vitamin C pada BTO dan BO menunjukkan hasil yang fluktuatif sampai hari ke-18. Adanya peningkatan kandungan vitamin $\mathrm{C}$ pada beberapa titik pengamatan disebabkan karena belimbing masih mengalami respirasi, sehingga masih terjadi proses metabolisme menuju tingkat kematangan. BTO dan BO terus mengalami penurunan kandungan vitamin $C$ pada hari ke-20 hingga ke-28. Penurunan vitamin $\mathrm{C}$ terjadi akibat adanya proses oksidasi (Anggraini dkk., 2015). Menurut Helmiyesi dkk. (2008), secara umum reaksi oksidasi vitamin C ada dua macam yaitu proses oksidasi spontan akibat reaksi dengan udara sekitar dan proses oksidasi tidak spontan akibat enzim katalisator.

Mekanisme oksidasi spontan terjadi sebagai berikut: monoanion asam askorbat merupakan sasaran penyerangan oksidasi oleh molekul oksigen menghasilkan radikal anion askorbat dan $\mathrm{H}_{2} \mathrm{O}$ yang diikuti pembentukan dehidro asam askorbat dan hydrogen peroksida. Dehidro asam askorbat (asam L-dehidroaskorbat) merupakan bentuk oksidasi dari asam L-askorbat yang masih mempunyai keaktifan sebagai vitamin C. Namun asam L-dehidroaskorbat bersifat sangat labil dan dapat mengalami perubahan menjadi 2.3-L-diketogulonat (DKG). DKG yang terbentuk sudah tidak mempunyai keaktifan vitamin C lagi sehingga jika DKG tersebut sudah terbentuk maka akan mengurangi bahkan menghilangkan vitamin C yang ada dalam produk (Helmiyesi dkk., 2008).

\section{Kadar Air}

Grafik kadar air belimbing utuh selama penyimpanan 28 hari berbentuk polynomial kubik (Gambar 3). Persamaan pada Gambar 3 memiliki arti bahwa hubungan antara lama penyimpanan terhadap

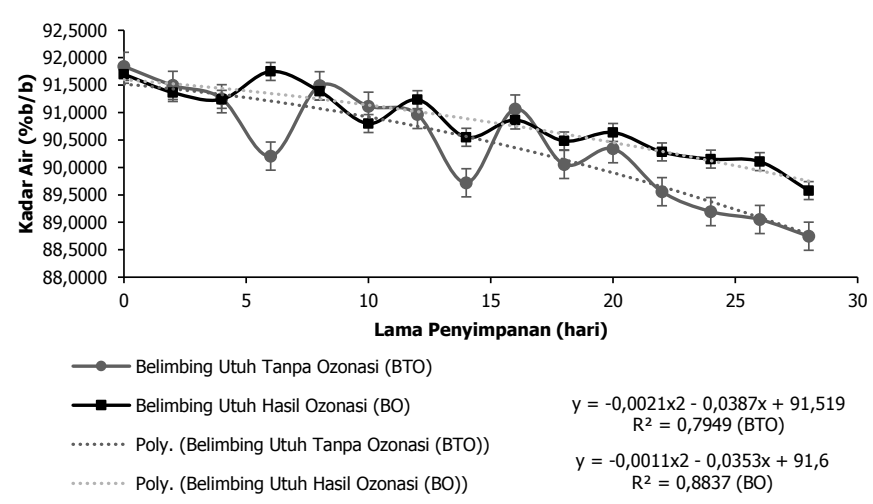

Gambar 3. Grafik kadar air pada BTO dan BO belimbing selama penyimpanan pada suhu ruang kadar air belimbing bersifat polynomial kubik negatif atau mengalami penurunan untuk kedua sampel. Hubungan tersebut menunjukan setiap lama penyimpanan 2 hari, kadar air pada BTO akan menurun sebesar 0,14\% (b/b), sedangkan pada BO sebesar 0,05\% (b/b). Angka tersebut menunjukkan laju penurunan kadar air pada BTO lebih cepat dibandingkan BO.

Hasil pengamatan kadar air pada kedua perlakuan mengalami hasil yang fluktuatif hingga hari ke18. Kenaikan kadar air bisa disebabkan terjadinya penyesuaian buah dengan kelembaban udara yang mengakibatkan buah menyerap air dari lingkungan. Kadar air BTO maupun BO terus mengalami penurunan pada hari ke-20 hingga ke-28. Penurunan kadar air BO dan BTO selama penyimpanan pada suhu ruang disebabkan karena buah tetap melangsungkan aktivitas metabolisme dengan hilangnya sebagian air lewat peristiwa transpirasi. Transpirasi merupakan proses penguapan air dari jaringan tanaman yang terjadi secara terus menerus akibat adanya perbedaan potensial air pada jaringan tersebut (Utama, 2013).

BO memiliki kadar air awal sebesar 39,01\% (b/b) dan kadar air akhir sebesar 31,97\% (b/b). BTO memiliki kadar air sebesar 38,03\% (b/b) dan kadar air akhir sebesar 30,49\% (b/b). Hal ini menunjukkan BO memiliki kadar air lebih tinggi dibandingkan BTO. Lebih tingginya kadar air BO disebabkan oleh proses perendaman. Proses perendaman ini mengakibatkan adanya air yang terdifusi masuk ke dalam jaringan belimbing yang dapat meningkatkan kadar air belimbing.

\section{Total Mikroorganisme}

Grafik total mikroorganisme belimbing utuh selama penyimpanan 28 hari berbentuk polynomial kubik (Gambar 4). Persamaan pada Gambar 4 memiliki arti bahwa hubungan antara lama penyimpanan terhadap

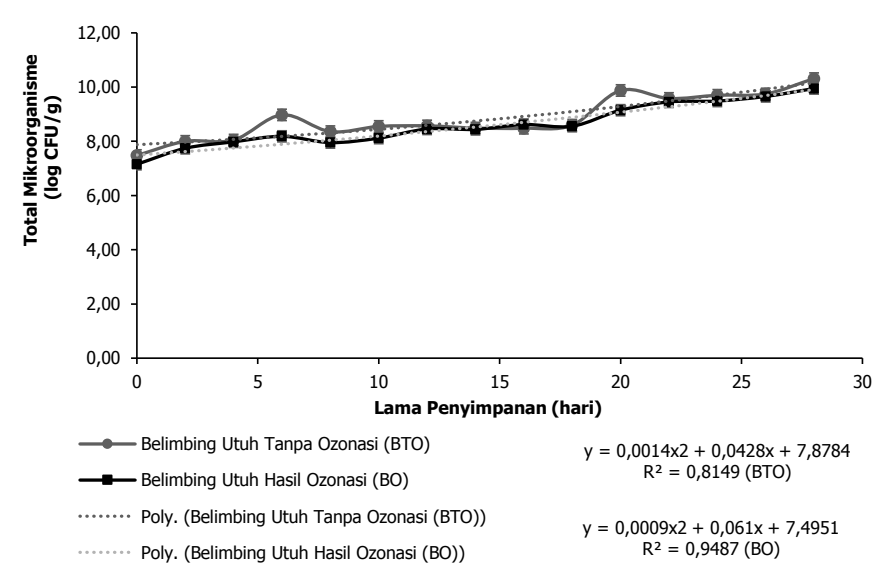

Gambar 4. Grafik total mikroorganisme pada BTO dan BO belimbing selama penyimpanan pada suhu ruang 
total mikroorganisme belimbing bersifat polynomial kubik positif atau mengalami peningkatan untuk kedua sampel. Hubungan tersebut menunjukkan setiap lama penyimpanan 2 hari, total mikroorganisme pada BTO akan meningkat sebesar 0,3913 log CFU/g, sedangkan pada BO sebesar 0,2942 log CFU/g. Angka tersebut menunjukkan laju peningkatan total mikroorganisme pada BTO lebih cepat dibandingkan BO.

Total mikroorganisme selama penyimpanan pada BO cenderung lebih rendah dibandingkan dengan total mikroorganisme BTO. Pemberian air berozon yang dapat mereduksi total mikroorganisme disebabkan oleh reaksi ozon dengan kontaminan secara langsung (sebagai molekul $\mathrm{O}_{3}$ ) atau tidak langsung (dalam bentuk radikal bebas). Sifat oksidasi yang kuat pada ozon dapat menyebabkan denaturasi albumen bakteri dan merusak sistem enzim sehingga bakteri terdekomposisi dan akhirnya mati (Miller dkk., 2013).

Jumlah mikroorganisme pada BTO dan BO mengalami peningkatan \pm 2 log $\mathrm{CFU} / \mathrm{g}$ selama penyimpanan 28 hari. Gambar 4 menunjukan peningkatan mikroorganisme pada BTO tidak berbeda jauh dengan $\mathrm{BO}$. Hal ini menunjukan bahwa ozon dengan konsentrasi 1,1 ppm kurang efektif dalam menurunkan mikroorganisme pada belimbing selama penyimpanan. Air ozon dengan konsentrasi 1,1 ppm yang digunakan untuk mencuci belimbing, hanya dapat menghambat pertumbuhan mikroorganisme sebesar 0,37 log CFU/g .

\section{KESIMPULAN}

Proses ozonasi menyebabkan terjadinya penurunan kekerasan, vitamin $C$, dan kadar air belimbing utuh hasil ozonasi (BO) berturut-turut sebesar 56,36\%; 18,04\%; dan 2,31\%; Belimbing utuh tanpa ozonasi (BTO) juga mengalami penurunan kekerasan, dan vitamin $\mathrm{C}$ berturut-turut sebesar 56,21\%; 19,84\%; dan 3,37\% selama penyimpanan 28 hari pada suhu ruang. Ozonasi dapat menghambat pertumbuhan mikrorganisme sebesar 0,34 log CFU/g.

\section{UCAPAN TERIMA KASIH}

Makalah ini telah dipresentasikan pada seminar internasional PATPI 2016 di Jakarta. Penulis mengucapkan terima kasih kepada Kementrian Riset, Teknologi, dan Pendidikan Tinggi atas bantuan dana yang diberikan untuk penelitian ini melalui Penelitian Unggulan Perguruan Tinggi (PUPT) Bidang Unggulan Pangan Lokal dan Pangan Nasional serta Univesitas Padjadjaran yang telah memfasilitasinya.

\section{DAFTAR PUSTAKA}

Anggraini, R., Hasbullah, R., dan Sutrisno. 2015. Studi Degreening pada jeruk cultivar keprok madu terigas Kalimantan Barat. Jurnal Penelitian Pascapanen Pertanian, 12(1) 37:46.

AOAC. 2005. Official Methods of Analysis of The Association of Analytical Chemist. Washington DC.

Badan Pusat Statistik dan Direktorat Jenderal Hortikultura. 2014. Konsumsi Perkapita Buah-Buahan di Indonesia Periode 2010-2014. Available at www.hortikultura. deptan.go.id. Diakses pada tanggal 21 Maret 2016.

Badan Pengawasan Obat dan Makanan (BPOM). 2008. Pengujian Mikrobiologi Pangan. Infopom, 9 (2): 1-11.

Chauhan, O.P., Raju, P.S., Ravi, N., Asha, S., and Bawa, A.S. 2011. Effectiveness of ozone in combination with controlled atmosphere on quality characteristics including lignification of carrot sticks. Journal of Food Engineering, 102. 43-48.

Halimah, R. 2012. Keragaan agribisnis belimbing (Averhoa carambola) (studi kasus pada Kelompok Tani Maju Bersama, Kelurahan Tugu, Kecamatan Cimanggis, Kota Depok). Skripsi. Program Studi Agribisnis, Fakultas Pertanian, Universitas Padjadjaran.

Helmiyesi, Hastuti, R. B., dan Prihastanti, E. 2008. Pengaruh lama penyimpanan terhadap kadar gula dan vitamin $C$ pada buah jeruk siam. Buletin Anatomi dan Fisiologi, XVI (2).

Karinda, M. Fatimawali, Gayatri, C. 2013. Perbandingan Hasil Penetapan Kadar Vitamin C Mangga Dodol Dengan Menggunakan Metode Spektrofotometri Uv-Vis dan Iodometri. Pharmacon - Jurnal Ilmiah Farmasi Unsrat, 2. ISSN $2302-2493$.

Manaco, K.A., Costa, S.M., Uliana, M.R., dan Lima, G.P.P. 2014. Sanitizer Effect in Mango Pulp and Peel Antioxidant Compounds. Food and Nutrition Sciences. http:// www.scirp.org/journal/fnshttp://dx.doi.org/10.4236/ fns.2014.510103. [May 2014].

Martín-Belloso O., Soliva-Fortuny R. 2011. Advances in FreshCut Fruits and Vegetables Processing. Taylor and Francis Group, LLC; Boca Raton, 410p.

Miller. 2013. Vitamin and mineral contents of carrot and celeriac grown under mineral or organic fertilization. [Online] Available from: http://www.sarep.ucdavis. edu/newsik/components/v3n1/sa-5.htm. [diakses pada tanggal 2 Juni 2017].

Musaddad, D. 2013. Kajian Pengaruh Ozon, Kemasan Plastik Dan Suhu Penyimpanan Terhadap Keamanan, Mutu dan Umur Simpan Kubis Bunga Diolah Minimal. Disertasi Program Pascasarjana Universitas Padjadjaran, Bandung. 
O’Donnell, C., Tiwari, B.K., Cullen, P.J., dan Rice, R.G. 2012. Ozone in Food Processing. Wiley-Blackwell, Oxford.

Syafutri, M.I., Pratama, F., dan Saputra, D. 2006. Sifat Fisik dan Kimia Buah Manga (Mangifera indica L.) Selama Penyimpanan dengan Berbagai Metode Pengemasan. Jornal Teknologi dan Industri Pangan, Vol 17 (1).

Sung, H.J., Song, W.J., Kim, K.P., Ryu, S. Kang, D.H. Combination effect of ozone and heat treatments for the inactivation of Escherichia coli 0157:H7, Salmonella Typhimurium, and Listeria monocytogenes in apple juice. Int.J. of Food Microb, 171(2014) 147-153.
Utama, I. M. S., dan Antara, N. S. 2013. Pasca Panen Tanaman Tropika: Buah dan Sayur. Bahan Ajar. Tropical Plant Curriculum Project. Universitas Udayana, Bali.

Wei, K.J., Zhou H.D., Zhou, T., Gong, J.H., 2007. Comparison of Aqueous Ozone and Chlorine as Sanitizers In The Food Processing Industry: Impact On Fresh Agricultural Produce Quality. Ozone-Sci Eng, 29(2):113-120. 